\title{
Sustainable Sport Tourism Destination in Banyuwangi
}

Panji Sekar Pambudi, M.Pd. , Prof. Dr. Nurhasan, M. Kes., Dr. Nining Widyah Kusnanik, M.Appl. Sc.

Postgraduate of Sport Science Faculty Surabaya State University, Surabaya, Jawa Timur, Indonesia

DOI: $10.36348 / \mathrm{sb} .2020 . \mathrm{v} 06 \mathrm{i} 07.002$

| Received: 13.03.2020 | Accepted: 21.03.2020 | Published: 30.07.2020

*Corresponding author: Panji Sekar Pambudi

Abstract

This research has an aim to examine the role of Sport Tourism through the program of Banyuwangi festival (B-Fest) and the impact of local content and deciding sustainable strategy of Sport Tourism Development. This research uses descriptive associative research method with qualitative and quantitative approach. Data Collection method done by observation, direct interview, questionnaire and collect the data from related instance. The result of this analysis shows that (1) Banyuwangi Festival Program (B-fest) successfully increase the number of visitor in Kawah Ijen and Pulau Merah within total contribution of 75,9\% (2) the effect of sport tourism toward the change of local community in Kawah Ijen, on economic aspect contribute 100\%. On social aspect contribute 11,6\%. Environmental aspect, edelweiss flower no longer to be seen, Javan lutung and deer are rarely to be seen. Social Aspect contribute 2,6\% toward people prosperity, $0,2 \%$ toward local satisfaction, $12,7 \%$ toward people participation. (3) Development strategy on sustainable sport tourism using the model of Sport tourism Participation and oriented to tourism characteristic.

Keyword: sport tourism role, the effect on local content, sustainable development strategy.

Copyright @ 2020: This is an open-access article distributed under the terms of the Creative Commons Attribution license which permits unrestricted use, distribution, and reproduction in any medium for non-commercial use (NonCommercial, or CC-BY-NC) provided the original author and source are credited.

\section{INTRODUCTION}

Sport tourism as a part of Banyuwangi Festival Event already implemented since 2012-2018 and focused on priority tourism place in Banyuwangi, such as Pulau Merah and Kawah Ijen. Promotion activity on both of tourism place is sport championship like International Surfing and bike racing International Tour de Banyuwangi Ijen (ITdBI). Those two activities designed in such a way passing through tourism destination. Thus, through that, expected to introduce tourism destination and gain more interest from traveller.

Generally, tourist destination being known as an effort to improve people prosperity and to help economic development of society [1]. A good and consistent cooperation between every stakeholder can cause any positive impact to improve social prosperity through tourist destination and bring the real effect of improving global competitiveness and foreign exchange earnings through community based tourism [2].

Tourist attraction in district area is a part of regional development which is expected to give positive impact such as working opportunities for people, increase regional income and people income and leads into positive activities for youth generation [3].

The contribution of sport tourism being packed through program of 'Banyuwangi Festival' not certainly measured of how much its contribution for economic growth and social condition of local people in tourist area. Related to that matter, there is no relevant information of whether the government program of 'Banyuwangi Festival' consider as suitable for people within continuity, thus, this point considered as an interesting matter to be studied deeply.

\section{LITERATURE FRAMEWORK Tourism and Sport}

Visiting one place to enjoy certain purpose or activities can be called as tourism activities. Thus, tourism activities is every activities which visiting tourism destination and being supported by every facilities and services provided by people around tourist destination, entrepreneur, government and regional government [11].

Sport is every systematic activity to support, guide and develop physical potential, spiritual and social [10]. 
Therefore, what it means by sport tourism is every kind of tourism activities being arranged and planned by traveller itself during certain time and makes a pleasure to enjoy the time or the moment.

\section{The role of Sport Tourism}

Tourism is one of new industry which is able to provide a rapid economic development on employment opportunity, income, living standard and activating other production sectors inside the country of tourism destination [4]

Therefore, the role of participated people and stakeholders should be in one way. Moreover, to introduce various kind of culture of one region, need an interesting point to catch tourist attention, therefore the existence of sport tourism and it competition can be used as an effective way to improve an attractive point of a destination and that will involve on economic development [5].

Banyuwangi Government held an annual event called Banyuwangi Festival. Banyuwangi Festival is one of promotional system to introduce Banyuwangi and its Tourism Destination. Furthermore, it will help Banyuwangi to increase their Economic-Social Aspect.

\section{The Effect of Sport Tourism}

Sport tourism can be defined as free motion medium of a person on spending his leisure time and enjoying a moment of competition and others. Sport and Tourism is an important point to improve economic aspect for developing and developed country [6].

Sport as a tourist attraction make a positive impact to state financial condition through domestic sport tourism or sport for Indonesian people outside the place organizing the event in the form of Rupiah for event organizer, consumer, commercial sport, commercial non-sport, voluntary, government sectors [7].

\section{Tourism Service and Management Standard}

Standardization system of tourism service and management is significantly important because it makes a benefit for customer, entrepreneur, government, environment and local community. There are some way of standardization on tourism management and service: 1) standard on managing natural tourism place. It includes: ecosystem conservation, preserving tourist attraction object, preserving socio-culture, satisfaction, safety, visitor convenience, economic benefit for people 2) Standard of service on people and natural tourist destination include a good service for visitor, visitor safety, ecosystem function maintenance, efficiency and energy saving.

\section{Development of Sustainable Tourism}

The concept of 'sustainable development' is an idea to adjust the current need and did not leave future generation needs; there are three principles on sustainable development: ecology, socio-cultural and economical factor for current era and future era. Sustainable development can be a process of developing the tourism place within the purpose of conserving natural resources for the sake of the future, however socio-cultural and economy as important resources on tourism development [8].

Thus, the concept of sustainable development is a hope for every people who understand the meaning of sustainable itself which involved ecology aspect, social aspect, cultural aspect, and economic aspect. Therefore, it needs a better plan which can be integrated strictly by every stakeholder on its way to create a good sustainable tourism development, especially in sport category.

\section{Conceptual Framework}

On the aspect of society, people around tourism destination preparing them to support tourism needs within the guarantee of safety, hygiene, convenience, guide, home stay, café \& resto, local culture, souvenir and event.

Therefore, if the activities around tourism destination have a good management system and there is a good synergy between people and government, it will cause a positive effect such as the development in economic aspect, income and working opportunities for people around. Thus, the number of jobseeker will be declined and prosperity of local people will be rapidly increased. 


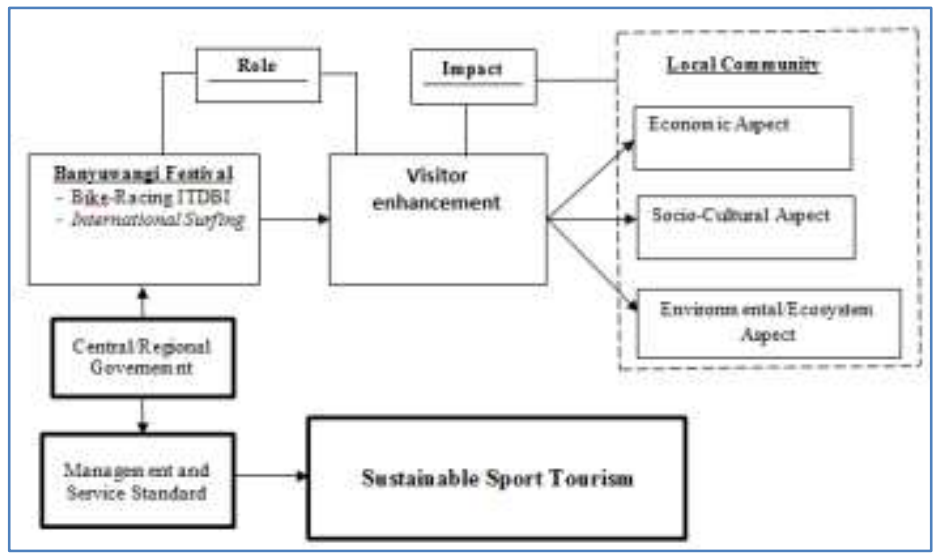

Gambar-4.1: Skematik Kerangka Konseptual

\section{RESEARCH METHODOLOGY \\ Research Types}

This research is a descriptive associative research using the combination approach of qualitative and quantitative. Descriptive researcher describes any event and explained it qualitatively. While associative research is a correlational research to analyze the relation between the variable of tourism growth and the change of local community around tourism area of Kawah Ijen and Pulau Merah.

\section{Research Subject}

Subject of this research divided into some part: visitor, local people, public figure, tour and travel agency which include Banyuwangi, hotel, restaurant, related official instrument such as: Village Instrument, BPS, DISBUDPAR, BAPPEDA, BKSDA, and KPH South Banyuwangi.

\section{Data Collection}

Data Collection Technique within observation, interview, spreading questionnaire, and data archive from some related instance such as: Village Instrument, BPS, DISBUDPAR, BAPPEDA, BKSDA, KPH South Banyuwangi.

\section{Data Analysis}

To understand how big the contribution of sport tourism program as a way to promote tourist destination. There are four factors of promoting tourist destination (information, satisfaction level, visiting enthusiast, and recommend it to others). Therefore, individually (each factor) done by statistical analysis crosstabulation and chi square trial, while overall factor (simultaneous) using method of logistic regression analysis. while to understand how much the impact for local content, analysis technique divided into a) economic aspect using correlation pearson, b) social aspect using crosstabulation and chi square trial and c) environmental aspect using qualitative data analysis.

\section{RESULT}

\section{The role of Sport as Tourism}

Survey outcome indicates that the program of Banyuwangi Festival (B-Fest) capable to increase the number of visitor in Kawah Ijen and Pulau Merah. There are four factors which has significant role on that success: information, visitor satisfaction, visitor enthusiasm and the ability to recommend any destination simultaneously.

The analysis result of individual correlation between the implementation of sport tourism activities (B-Fest) toward the increase visitor number of each indicator can be seen from table 1 below:

Table-1: The result of coefficient correlation ( $r$ )

\begin{tabular}{|c|c|c|c|c|c|c|}
\hline No & Indicator & Method & & Value & $\begin{array}{l}\text { Approximate } \\
\text { Significance }\end{array}$ & Note \\
\hline \multirow{2}{*}{1} & \multirow{2}{*}{ Information } & Interval by Interval & Pearson's R & 0,623 &, $000 \mathrm{c}$ & Significant \\
\hline & & Ordinal by Ordinal & Spearman Correlation & 0,623 &, $000 \mathrm{c}$ & Significant \\
\hline \multirow{2}{*}{2} & \multirow{2}{*}{$\begin{array}{l}\text { Visitor } \\
\text { Satisfaction }\end{array}$} & Interval by Interval & Pearson's R & 0,667 &, $000 \mathrm{c}$ & Significant \\
\hline & & Ordinal by Ordinal & Spearman Correlation & 0,670 & ,000c & Significant \\
\hline \multirow{2}{*}{3} & \multirow{2}{*}{$\begin{array}{l}\text { Visitor } \\
\text { enthusiasm }\end{array}$} & Interval by Interval & Pearson's R & 0,510 &, $000 \mathrm{c}$ & Significant \\
\hline & & Ordinal by Ordinal & Spearman Correlation & 0,521 &, $000 \mathrm{c}$ & Significant \\
\hline \multirow{3}{*}{4} & \multirow{2}{*}{$\begin{array}{l}\text { Recommen } \\
\text { dation }\end{array}$} & Interval by Interval & Pearson's R & 0,218 &, $029 \mathrm{c}$ & Significant \\
\hline & & Ordinal by Ordinal & Spearman Correlation & 0,218 &, $029 \mathrm{c}$ & Significant \\
\hline & \multicolumn{3}{|c|}{$\mathrm{N}$ of Valid Cases } & 100 & & \\
\hline
\end{tabular}


According to the analysis of individual correlation it can be seen that 1) information indicator known as value pearson $R$ and spearman correlation has the same number of 0,623 and significant score of 0,000 . It means that the increase number of visitor has significantly explained by information indicator. 2) Satisfaction indicator of visitor known as value pearson $R$ of 0,667 and spearman correlation of 0,670 within the same significant score of $0,000.3$ ) enthusiasm indicator of visitor with the value of pearson $\mathrm{R}$ of 0,510 and spearman correlation of 0,521 with the same significant number of 0,000. 4) Recommendation indicator known with value of pearson $R$ and spearman correlation of 0,218 and significant value of 0,029 .

Simultaneously analysis result can be seen on Table 2 above:

Table-2: Coefficient Calculation Result

\begin{tabular}{|c|c|c|c|c|c|c|c|}
\hline \multicolumn{8}{|c|}{ Variables in the Equation } \\
\hline & & $\mathrm{B}$ & S.E. & Wald & $\mathrm{df}$ & Sig. & $\operatorname{Exp}(B)$ \\
\hline \multirow{5}{*}{$\begin{array}{l}\text { Step } \\
1^{\text {a }}\end{array}$} & Information (x1) & 3,004 & 882 & 11,589 & 1 & 001 & 20,169 \\
\hline & $\begin{array}{l}\text { Satisfaction Level } \\
\text { (x2) }\end{array}$ & 4,117 & 1,194 & 11,881 & 1 & ,001 & 61,349 \\
\hline & $\begin{array}{l}\text { Visitor Enthusiasm } \\
\text { (x3) }\end{array}$ & 2,307 & ,650 & ,223 & 1 & ,037 & 1,359 \\
\hline & $\begin{array}{l}\text { Recommendation } \\
\text { to others }(\mathrm{x} 4)\end{array}$ & 4,341 & 1,366 & 10,091 & 1 & ,001 & ,013 \\
\hline & Constant & $\begin{array}{r}- \\
13,851\end{array}$ & 3,709 & 13,946 & 1 & ,000 & ,000 \\
\hline
\end{tabular}

Based on table 3 it can be known the total coefficient of each estimator parameters, therefore logistic regression as what written below:

$$
\begin{aligned}
& \operatorname{Ln} \frac{p}{1-p} \quad=\mathrm{a}+\mathrm{b}_{1} \mathrm{x}_{1}+\mathrm{b}_{2} \mathrm{x}_{2}+\mathrm{b}_{3} \mathrm{x}_{3}+\mathrm{b}_{4} \mathrm{x}_{4} \\
& =-13,851+3,004 x_{1}+4,117 x_{2}+2,307 x_{3}+4,341 x_{4} \\
& \frac{p}{1-p} \quad=e^{-13,851+3,004 \times 1+4,117 \times 2+2,307 \times 3+4,341 \times 4}
\end{aligned}
$$

The analysis of logistic regression indicated that those 4 variable (information, satisfaction level, visitor enthusiasm, and recommendation) are significant on the number of 0,05 . That result can be interpreted that $\log$ odds increase in number of visitor influenced by variable of information, satisfaction level, visitor enthusiasm and simultaneously recommendation.

Table-3: Hasil output Nilai $R$ square

\begin{tabular}{|l|c|c|c|}
\hline \multicolumn{4}{|c|}{ Model Summary } \\
\hline Step & $\begin{array}{c}-2 \text { Log } \\
\text { likelihood }\end{array}$ & $\begin{array}{c}\text { Cox \& Snell } \\
\text { R Square }\end{array}$ & $\begin{array}{c}\text { Nagelkerke R } \\
\text { Square }\end{array}$ \\
\hline 1 & $54,349^{\text {a }}$ &, 569 &, 759 \\
\hline \multicolumn{3}{|c|}{$\begin{array}{l}\text { a. Estimation terminated at iteration number 7 because } \\
\text { parameter estimates changed by less than ,001. }\end{array}$} \\
\hline
\end{tabular}

Based on table 4 Nagelkerke $R$ Square can be interpreted as $\mathrm{R}^{2}$ on multiple regressions. Output result SPSS giving Nagelkerke $R$ Square of 0,759 means that variability of dependent variable can be explained by independent variable of $75,9 \%$. In other world that BFest simultaneously contribute $75,9 \%$ toward the increase of visitor number.

\section{The effect on Local Content Local Content on Kawah Ijen} The effect on economical aspect

Economical aspect include 3 indicators such as: ticketing income, entrepreneur income and the decrease of unemployment number. To understand how much the impact of improvement on the number of tourism can be seen below: 
Table-4: Analysis result of correlation and contribution of tourism increase toward economical aspect

\begin{tabular}{|c|l|c|c|c|}
\hline \multicolumn{2}{|c|}{} & $\begin{array}{c}\text { Ticketing } \\
\text { Income }\end{array}$ & $\begin{array}{c}\text { UMKM } \\
\text { Income }\end{array}$ & $\begin{array}{c}\text { The number of } \\
\text { unemployment }\end{array}$ \\
\hline \multirow{2}{*}{$\begin{array}{c}\text { The increase } \\
\text { of visitor } \\
\text { number }\end{array}$} & $\begin{array}{l}\text { Pearson } \\
\text { Correlation }\end{array}$ & 1,000 & 0,657 & $-0,605$ \\
\cline { 2 - 5 } & Kontribusi $\left(\mathrm{R}^{2}\right)$ & $100 \%$ & $43 \%$ & $37 \%$ \\
\cline { 2 - 5 } & Sig. $(2-t a i l e d)$ & 0,000 & 0,228 & 0,279 \\
\hline a Listwise N=5 & \multicolumn{4}{|l}{} \\
\hline
\end{tabular}

Based on the table above, it can be known that: 1) the increase number of visitor contributing on ticketing income $100 \%, 2$ ) the increase number of visitor contributing on entrepreneur income around $43 \%$ and 3) the increase number of visitor contributing on reduction of unemployment around $34 \%$.

\section{The Effect on Social Aspect}

Social Aspect involved 3 aspects which are: prosperity, local satisfactory, social participation. Here is the result of the effect on visitor change of each indicator.

Table-5: Result of correlation between the amount of visitor and the change of social condition in Kawah Ijen

\begin{tabular}{|l|l|c|c|c|}
\hline \multirow{2}{*}{} & & \multicolumn{3}{|c|}{ Social Aspect Indicator } \\
\cline { 3 - 5 } & & Prosperity & Local Satisfaction & People Participation \\
\hline \multirow{3}{*}{ Visitor Number } & Pearson Correlation & 0,340 & 0,333 & 0,666 \\
\cline { 2 - 5 } & Contribution (R2 ) & $11,6 \%$ & $11,1 \%$ & $44,40 \%$ \\
\cline { 2 - 5 } & Sig. (2-tailed) & 0,001 & $0,001 \mathrm{c}$ & 0,22 \\
\hline
\end{tabular}

Based on the table above, correlation result of pearson $R$ about 0,340 with significant $(0,001>0,05)$, and the contribution value of $\left(\mathrm{R}^{2}\right)=\left(0,340^{2}\right)=11,6 \%$. It can be said that the increase number of visitor in Kawah Ijen contribute $11,6 \%$ toward the prosperity of people in Tamansari village. Correlation result indicates pearsons $R$ of 0,333 within the significant of $(0,001>0,05)$ and the amount of contribution $\left(\mathrm{R}^{2}\right)=\left(0,333^{2}\right)=11,1 \%$. The implementation of sport tourism event positively contribute $11,1 \%$ toward local satisfaction of Tamansari village. Pearson correlation of 0,666 within the significant of $(0,22>0,05)$ an value of $R^{2} 44,4 \%$. Thus, the increase off bisitor number contribute $44,4 \%$ toward the number of entrepreneur in Tamansari village.

\section{The effect on environmental aspect}

These are the result of local community development on environmental and ecosystem aspect around Kawah Ijen (Tamansari Village).

\section{Conservation of Natural Resources}

Conservation of water resource done by regularly cleaning the main resource of clean water. Conservation on air factors is only a matter of the effect of sulfur fumes. The effort to minimalize the fumes prohibited the visitor of being close to the source of sulfur fumes because it contains of toxic and can destroy human respiration system. Besides, around
Kawah Ijen there are many people selling mask for protection.

Conservation of Flora and Fauna doing by attached warning board on every place to support environment preservation of Flora and Fauna.

\section{Impact Restriction}

Restriction of impact on liquid waste usually comes from public toilet around the tourism area. To prevent any harm caused by liquid waste, there should be a sewer exists of each public toilet or WC.

Restriction of trash impact doing by close the area at certain time and give the cleaning team time to clean tourism area. It is done regularly by Friday of first week.

Restriction on the impact of fire hazard doing by providing every firefighters support for 24 hours to maintain the area, in case there will be a fire happen in unpredictable times.

\section{Local Content of Pulau Merah}

The Effect on Economical Aspect

Calculation result of the influence on decrease of visitor number in Pulau Merah from economic aspect can be seen on table indicator below. 
Panji Sekar Pambudi et al., Sch Bull, July, 2020; 6(7): 182-188

Table-6: Total correlation of tourism number toward the change of Pulau Merah's economic condition

\begin{tabular}{|c|l|c|c|c|}
\hline \multicolumn{2}{|c|}{} & $\begin{array}{c}\text { Ticketing } \\
\text { Income }\end{array}$ & $\begin{array}{c}\text { UMKM } \\
\text { Income }\end{array}$ & $\begin{array}{c}\text { The amount of } \\
\text { unemployment people }\end{array}$ \\
\hline \multirow{2}{*}{$\begin{array}{c}\text { The number } \\
\text { of tourist }\end{array}$} & $\begin{array}{l}\text { Pearson } \\
\text { Correlation }\end{array}$ & 0,939 & $-0,44$ & 0,501 \\
\cline { 2 - 5 } & $\begin{array}{l}\text { Contribution } \\
\left(\mathrm{R}^{2}\right)\end{array}$ & $88,2 \%$ & $19,4 \%$ & $25,1 \%$ \\
\cline { 2 - 5 } & Sig. (2-tailed) & 0,006 & 0,382 & 0,312 \\
\hline a Listwise N=6 & & & \\
\hline
\end{tabular}

Based on the table above, it indicates that: 1) the amount of tourist make an influence on ticketing income around $88,2 \%, 2$ ) the amount of tourist make an influence on the income of entrepreneur around $19,4 \%$ and 3 ) the amount of tourist make an influence on reduction of unemployment people around $25,1 \%$.

\section{The Effect on Social Aspect}

The following below are the result of the impact of the change on visitor number.

Table-7

\begin{tabular}{|c|l|c|c|c|}
\hline \multirow{2}{*}{} & & \multicolumn{3}{|c|}{ Social Aspect Indicator } \\
\cline { 3 - 5 } & Prosperity & $\begin{array}{c}\text { Local } \\
\text { Satisfaction }\end{array}$ & $\begin{array}{c}\text { People } \\
\text { Participation }\end{array}$ \\
\hline \multirow{3}{*}{$\begin{array}{c}\text { Number of } \\
\text { visitor }\end{array}$} & Pearson Correlation & $-0,161$ & 0,04 & 0,356 \\
\cline { 2 - 5 } & Contribution (R2) & $2,6 \%$ & $0,2 \%$ & $12,70 \%$ \\
\cline { 2 - 5 } & Sig. (2-tailed) & 0,111 & $0,694 \mathrm{c}$ & 0,489 \\
\hline
\end{tabular}

Based on the table above, the correlation result indicates that value of pearson $R$ and spearman correlation has the same value of $-0,161$ within the significance of $(0,111>0,05)$ or the amount of contribution $\left(\mathrm{R}^{2}\right)=\left(-0,161^{2}\right)=2,6 \%$. This can be explained that the change of visitor number in Pulau Merah make an influence of $2,6 \%$ toward people in Sumberagung's prosperity.

Correlation result indicates that the value of pearson $R$ of 0,040 within significance of $(0,694>$ $0,05)$, and the contribution $\left(R^{2}\right)=\left(0,040^{2}\right)=0,2 \%$. Thus can be explained that the amount of visitor only contributed $0,2 \%$ toward local satisfaction of people in Sumberagung.

Based on the table above, can be indicated that: pearson correlation with 0,356 within the significance value of $(0,489>0,05)$ and $R^{2}$ is $12,7 \%$. The change of visitor number involve $12,7 \%$ toward the number of enterpreuner in Sumberagung Village.

\section{The effect on Environmental Aspect}

Those are the result of local community and ecosystem development in Pulau Merah (Sumberagung village).

\section{Protection of Natural Resources}

Conservation of clean water doing by taking care of water resources such as water well and water pump. Therefore, clean water can be stream through public toilet and worship place.

\section{Management of Natural Resources}

Energy management (electricity) in Pulau Merah, electricity supply gain from State Electricity Company (PLN). Management system of clean water by building some wells around tourism area for the needs of public toilet.

\section{Impact Limitation}

Limitation on the impact of trash in Pulau Merah done by activating ecorenger as the selected employee to clean all the trashes around tourism area and gave a public counseling for people of how to manage organic trash into non-organic trash.

\section{Development Strategy}

Development Model used here is Sport Tourism Participation Model. According to Weed and Bull [9], Sport Tourism Participation Model is dynamic model to improving knowledge of sport tourism behavior, how the effect of tourist destination is and how the management works to improve successful sport tourism. Here are the stages to improve the model of sport tourism participation.

\section{Basic Knowledge}

Basic thinking on this development of this research identified in some point : 1) decrease on the number of visitor in Pulau Merah, 2) Decline on income of entrepreneur in Pulau Merah, 3) decline on satisfaction level of visitor in Pulau Merah, and 4) hold international surfing event which these past few year has been forgotten in Pulau Merah. 
Panji Sekar Pambudi et al., Sch Bull, July, 2020; 6(7): 182-188

\section{Target and Aims}

The focus of this sport tourism development is to invite the visitors for participate on sport activities as participant not only as viewer

\section{The Steps of Development Strategy}

Participation Model of Sport Tourism oriented on the object of tourism place which have various kind of characteristic such as insidential, sporadic, occasional, and regular and committed tourism. For sporadic and insidential tourism, there will be an activity called tourism with sport content such as beach volleyball, beach soccer, jogging, bicycling, and horseriding. For occasional tourism there will be an activity with recreation purpose and training sport such as surfing with the right guidance. While for committed tourism, there will be training sport and event competition such as: bike racing of tour de Ijen, surfing competition and triathlon competition.

\section{CONCLUSION}

Based on the explanation above, it can be concluded that (1) Banyuwangi Festival Program (BFest) successfully increase the number of visitor in Kawah Ijen and Pulau Merah with total contribution of $75,9 \%$. (2) the impact of sport tourism toward the change of local community in Kawah Ijen, on economical aspect contribute $100 \%$ for ticketing, $43 \%$ for people income, $37 \%$ for decreasing the amount of unemployment. On social aspect contribute $11,6 \%$ for poverty, $11,1 \%$ for local satisfaction and $44,4 \%$ for people participation. (3) Sustainable Sport Tourism Development Strategy using the model of Sport Tourism Participations oriented to Tourism characteristic. Development using three kind of categories of sport tourism which is 1) tourism with sport content category 2) training sport category which mean the provider of tourism facility within the provider of sport training 3) event competition category which provide any tourism facility by having sport championship event.

\section{SUGGESTION}

For the tourism management, this research can be an input material and references to improving quality of sport tourism facility provisions and can be used to improve the potential of tourism visit with an environment friendly, therefore the originality of natural resources will remain preserved.
For academic subject, the result of this analysis can be used as additional insight knowledge of sport tourism within a good continuity and rule of not destroying any component of environment.

\section{REFERENCES}

1. Damanik, P. (2013). Pariwisata Indonesia Antara Peluang dan Tantangan. Jogjakarta: Pustaka Pelajar.

2. Astuti, M. (2015). Potensi Wisata Olahraga dalam Meningkatkan Kunjungan Wisatawan. Jurnal Kepariwisataan Indonesia, 10(1), 31-40.

3. Prasetyo, P. (2013). Strategi Dinas Kebudayaan Pariwisata Pemuda dan Olagraga dalam Pengembangan Potensi Objek Wisata Kota Tarakan. E-Journal Ilmu Pemerintahan, 1(1), 151164.

4. Atan, S., \& Arslanturk, Y. (2012). Tourism and Economic Growth Nexus: An Input Output Analysis in Turkey. Procedia - Social and Behavioral Sciences. https://doi.org/10.1016/j.sbspro.2012.09.162

5. Barandela, J. S., Barajas, A., Alen, E., \& Fernandez, P. S. (2014). Modelling of Sport Events And Their Use to Increase Tourism And Economic Impact. Sport Tourism Conference, 114-124. Retrieved from https://www.researchgate.net/publication/28285198 5

6. Marumo, K., Lubbe, S., \& Pelser, T. (2015). Sport Tourism as a Developmental Initiative in The Economy of Mafikeng. African Journal of Hospitality, Tourism and Leisure, 4(2).

7. Vries, L. (2006). Presentasi, Internasional Seminar on Developing Marine Sport Tourism. Makassar.

8. Anom, I. (2010). Pariwisata Berkelanjutan Dalam Pusaran Krisis Global. Denpasar: Udayana University Press.

9. Weed, M., \& Bull, C. (2012). Sports tourism: Participants, policy and providers. In Sports Tourism: Participants, Policy and Providers. https://doi.org/10.4324/9780080474441

10. Undang-Undang RI No. 3 Tahun 2005 tentang Sistim Keolahragaan Nasional. (2005).

11. 2009., U.-U. R. I. N. 10. T. T. K. (2009). Undangundang republik indonesia nomor 10.tahun tentang kepariwisataan. Uud-ri kepariwisataan. https://doi.org/10.7202/1016404ar

12. Wahab, S. (2003). Manajemen kepariwisataan. 1. Pariwisata, industri - manajemen, Manajemen Kepariwisataan/Oleh Salah Wahab; Alih Bahasa Frans Gromang. https://doi.org/1992. 